\title{
MENGEMBANGKAN LITERASI INFORMASI MELALUI BELAJAR BERBASIS KEHIDUPAN TERINTEGRASI STEM UNTUK MENYIAPKAN CALON GURU SAINS DALAM MENGHADAPI ERA REVOLUSI INDUSTRI 4.0: REVIEU LITERATUR
}

\author{
Hasan Subekti ${ }^{1)}$, Mohammad Taufiq ${ }^{2)}$, Herawati Susilo ${ }^{3)}$, Ibrohim ${ }^{4)}$, and Hadi Suwono ${ }^{5)}$ \\ ${ }^{1}$ Universitas Negeri Surabaya \\ ${ }^{2}$ Universitas Nahdlatul Ulama Surabaya \\ 3,4,5 Universitas Negeri Malang \\ e-mail: herawati.susilo.fmipa@um.ac.id
}

\begin{abstract}
Abstrak: Perubahan dunia kini tengah memasuki era revolusi industri 4.0, di mana pola kehidupan manusia basis berbasis informasi. Dengan demikian, menyiapkan lulusan yang berkualitas dan mampu bersaing secara global, dan menguasai perkembangan teknologi merupakan hal yang penting untuk semua orang dan penting bagi masa depan suatu negara. Makalah ini mengupas tentang strategi mengembangkan literasi informasi melalui belajar berbasis kehidupan terintegrasi STEM untuk menyiapkan calon guru sains dalam menghadapi era revolusi industri 4.0. Secara rinci mengungkap Kajian itu meliputi (a) literasi informasi, (b) (b) keterampilan riset, (c) belajar berbasis kehidupan, (d) pembelajaran terintegrasi STEM, dan, (e) kapabilitas calon guru sains, dan (f) era Revolusi Industri 4.0. Kajian lebih mendalam tersaji dalam artikel ini.
\end{abstract}

Kata kunci: literasi informasi, riset, kapabilitas, STEM, revolusi industri 4

\begin{abstract}
The change of the world is now entering the era of industrial revolution 4.0, in which the pattern of human life base is information-based. Thus Preparing graduates who are qualified and able to compete globally, and mastering the development of technology is important for everyone and important for the future of a country. This paper explores the strategy of developing information literacy through STEM's integrated life-based learning to prepare prospective science teachers in the era of industrial revolution 4.0. In detail the study covered (a) information literacy, (b) (b) research skills, (c) life-based learning, (d) integrated learning of STEM, and, (e) prospective teacher science capabilities; and (f) era industrial revolution 4.0. A deeper study is presented in this article.
\end{abstract}

Keywords: literacy of information, research, capability, STEM, industrial revolution 4.0

\section{PENDAHULUAN}

Perubahan dunia kini tengah memasuki era revolusi industri 4.0 atau revolusi industri dunia keempat di mana teknologi informasi telah menjadi basis dalam kehidupan manusia (Kemristekdikti, 2018a). Menyiapkan lulusan yang berkualitas dan mampu bersaing secara global, dan menguasai perkembangan teknologi merupakan hal yang penting untuk semua orang dan penting bagi masa depan suatu negara (Kanematsu \&
Barry, 2016). Dengan demikian, dukungan dan peran pendidikan tinggi diharapkan untuk meningkatkan daya saing bangsa Indonesia di tengah persaingan global pesatnya perkembangan teknologi informasi.

Berkait dengan konteks Amanat dari Perpres No. 2 Tahun 2015 tentang Rencana Pembangunan Jangka Menengah Nasional (2015-2019) yang menyatakan bahwa peranan iptek diharapkan dapat memberikan kontribusi nyata terhadap perekonomian nasional (Kemristekdikti, 2017). 
Oleh karena itu, peningkatan kualitas pembelajaran sains merupakan salah satu tantangan bagi para dosen di program Studi Pendidikan Sains. Sejalan dengan alasan tersebut (Susilo, 2014) menyatakan bahwa dosen dihadapkan pada tantangan bagaimana menyiapkan calon-calon guru biologi (sains) yang profesional, yang adaptif terhadap perkembangan zaman. Adaptif dalam arti dapat menyesuaikan dengan tuntutan perkembangan ilmu pengetahuan dan teknologi.

Literasi informasi merupakan salah satu keterampilan berpikir tingkat tinggi yang dibutuhkan untuk mengembangkan dan mendukung kesuksesan akademis, profesional dan pribadi (Shao \& Purpur, 2016). Melatihkan literasi informasi dalam pembelajaran dan mengembangkan keterampilan riset secara mandiri diperlukan bagi profesional dalam pemasaran (Schroeter $\&$ Higgins, 2015). Bertolak dari paparan tersebut, urgensi penguasaan akan perkembangan dan kemajuan teknologi yang relatif dan aktivitas riset merupakan bagian penting dari kebutuhan dasar bagi setiap orang dan mendukung kesuksesan dalam menjalani kehidupan melalui kegiatan riset.

Riset merupakan sarana penting untuk meningkatkan mutu pembelajaran (Widodo, 2016: xxiv; Subekti \& Martini, 2016: 602). Komponen riset terdiri dari: latar belakang, prosedur, pelaksanaan, hasil riset dan pembahasan serta publikasi hasil riset. Seluruh komponen tersebut memberikan makna penting yang dapat dilihat cara memformulasi dan menyelesaikan permasalahan serta kemampuan dalam mengomunikasikan manfaat hasil penelitian (Widodo, 2016: xxiv).

Merujuk pada pandangan Staron (2011: 3) menyatakan "Life-based learning proposes that learning for work is not restricted to learning at work". Namun demikian, ungkapan Staron ini pun tidak cukup untuk kondisi Indonesia. Bagi masyarakat Indonesia belajar untuk bekerja merupakan sebagian saja dari kebutuhan hidup. Masih banyak kebutuhan lain yang harus dipenuhi seperti kebutuhan bersosialisasi, beribadah sesuai agama, memelihara lingkungan (hamemayu ayuning bhawana), menjaga tradisi kearifan lokal, bermasyarakat-berbangsa, bernegara (Sudira, 2015). Penekanan dari life-based learning ialah pengembangan ilmu pengetahuan untuk berkontribusi bagi kesejahteraan dan kebahagiaan masyarakat secara seimbang dan harmonis, sehingga menjadi sumber daya manusia yang andal. Ungkapan ini sejalan dengan pandangan (Firman, 2015) yang mengungkapkan bahwa upaya menghadapi era persaingan global, Indonesia pun perlu menyiapkan sumber daya manusia yang andal dalam disiplin-disiplin STEM secara kualitas dan mencukupi secara kuantitas.

Pendidikan STEM memiliki banyak manfaat potensial bagi individu dan bangsa secara keseluruhan (Beatty, 2011). Sejalan dengan uraian tersebut, (Bybee, 2013) mengemukakan tujuan dari pendidikan STEM, agar peserta didik memiliki literasi sains dan teknologi tampak dari membaca, menulis, mengamati, serta melakukan sains sehingga apabila mereka kelak terjun di masyarakat, mereka akan mampu mengembangkan kompetensi yang telah dimilikinya untuk diterapkan dalam menghadapi permasalahan dalam kehidupan sehari-hari yang terkait bidang ilmu STEM. Bertolak dari paparan (Herawati Susilo, Ibrohim, \& Suwono, 2017) menyatakan bahwa pengembangan kapabilitas siswa dan mahasiswa sangat penting karena di masa depan, mereka diharapkan dapat menciptakan lapangan kerja mereka sendiri, dan memecahkan permasalahan kehidupannya.

Kapabilitas itu adalah suatu karakter menyeluruh yang lebih mudah dikenali daripada didefinisikan. Kapabilitas yang dimaksudkan dalam konteks ini meliputi keterampilan, pengetahuan, dan sikap, yang akan dibawa seseorang 
Hasan Subekti, et al., Mengembangkan Literasi Informasi melalui Belajar Berbasis Kehidupan Terintegrasi STEM untuk Menyiapkan Calon Guru Sains dalam Menghadapi Era Revolusi Industri 4.0: Revieu Literatur

ke dunia kerja. Kapabilitas ini meliputi keahlian teknis, bisnis, personal, dan profesional, yang dapat dikembangkan melalui pembelajaran formal dan informal, pengamatan, pengarahan (mentoring), pemberian petunjuk (coaching), pemberian masukan, pengalaman sepanjang hayat dan refleksi diri. Orang yang kapabel itu tahu bagaimana cara belajarnya, kreatif, memiliki self efficacy tingkat tinggi, percaya diri dalam menerapkan kompetensinya, dan bekerja sama dengan baik dalam situasi yang sudah dikenal maupun situasi baru (Herawati Susilo et al., 2017).

Konseptualisasi kapabilitas bagi calon guru IPA" adalah suatu kepercayaan individu (self efficacy) dalam menerapkan konsep teoretis bidang keilmuan IPA, teori pedagogi, karakteristik perkembangan peserta didik, dan membangun kemampuan kinerja (berpikir kritis, penyelesaian masalah, komunikasi, kolaborasi, dan penguasaan teknologi digital) melalui pengalaman empiris, serta sikap (tanggung jawab) yang memperhatikan dan menerapkan budaya baik bangsa Indonesia (gotong royong, bhineka tunggal ika, sopan santun) dalam situasi yang sudah dikenal maupun situasi baru (Subekti, Susilo, Ibrohim, \& Suwono, 2017). Seturut dengan pandangan tersebut, (Sudira, 2015) menyatakan bahwa paradigma baru pembelajaran pun mengalami pergeseran dari proses menyerap pengetahuan dengan cara mengikuti perintah-perintah guru atau dosen, fokus hanya pada tes dan penilaian kognitif dengan peluang sangat terbatas, dan waktu pembelajaran terpola transaksi ke pembelajaran baru sebagai proses aktualisasi diri, self directing, self determine membangun perilaku menghargai diri sendiri dengan fokus pada belajar mandiri, belajar bagaimana belajar dengan baik, belajar dari berbagai sumber yang tidak terbatas isi, ruang, tempat, dan waktu melalui jaringan komputer. Hal ini sejalan dengan kecenderungan perubahan dunia saat ini yang telah memasuki era revolusi industri 4.0 saat ini.

Perubahan dunia kini tengah memasuki era revolusi industri 4.0 atau revolusi industri dunia keempat di mana teknologi informasi telah menjadi basis dalam kehidupan manusia. Segala hal menjadi tanpa batas (borderless) dengan penggunaan daya komputasi dan data yang tidak terbatas (unlimited), karena dipengaruhi oleh perkembangan internet dan teknologi digital yang masif sebagai tulang punggung pergerakan dan konektivitas manusia dan mesin (Kemristekdikti, 2018a). Seturut dengan pandangan tersebut (Zhong, et al., 2017) menyatakan Generasi di era industri 4.0 memegang komitmen peningkatan fleksibilitas di bidang manufaktur, secara massal, dengan kualitas dan produktivitas yang lebih baik. Imbasnya, Perubahan pesat yang dialami masyarakat karena pesatnya perkembangan teknologi informasi membawa banyak dampak pada kehidupan manusia, secara umum bersifat positif dan negatif (Hariastuti et al., 2017).

Menteri Ristekdikti Mohamad Nasir mengungkapkan "Revolusi industri 4.0 meliputi adanya persiapan untuk sistem pembelajaran yang lebih inovatif pada perguruan tinggi, atau menyesuaikan dengan kurikulum yang ada terkait perkembangan teknologi yang begitu pesat, sehingga, persiapan pada sistem jaringan harus dikembangkan secara terus-menerus," (Rialita, 2018). Berdasarkan uraian di atas, tujuan artikel ini mengeksplorasi tentang strategi mengembangkan literasi informasi melalui belajar berbasis kehidupan terintegrasi STEM untuk menyiapkan calon guru sains dalam menghadapi era revolusi industri 4.0.

\section{PEMBAHASAN}

Bagian ini berisi paparan tentang belajar berbasis kehidupan terintegrasi STEM dengan 
setting kkni untuk mengembangkan kapabilitas calon guru sains. Kajian itu meliputi (a) literasi informasi, (b) keterampilan riset (c) belajar berbasis kehidupan, (d) pembelajaran terintegrasi STEM, dan, (e) kapabilitas calon guru sains, dan (f) era revolusi industri 4.0. Hal tersebut dipaparkan secara teperinci sebagai berikut.

\section{Literasi Informasi}

Ragam definisi terkait literasi informasi (LI). Menurut The Association of College and Research Libraries (ACRL) "Information literacy is the set of integrated abilities encompassing the reflective discovery of information, the understanding of how information is produced and valued, and the use of information in creating new knowledge and participating ethically in communities of learning" (ACRL, 2016). Pendapat lain menyatakan penyelidikan terhadap literasi digital melalui perspektif literasi informasi yang lebih luas akan memberikan hasil yang lebih bermanfaat. Tema literasi informasi adalah (1) menentukan sifat dan tingkat kebutuhan informasi yang dibutuhkan, (2) mengakses informasi yang diperlukan, (3) menggunakan informasi secara efektif dan efisien, (4) penggunaan informasi etis dan hukum (Çoklar, et al., 2017), dan (5) mengevaluasi informasi dan sumbersumbernya secara kritis dan menggabungkan informasi terpilih ke dalam pengetahuan yang sudah dimiliki sebelumnya dan sistem nilai (Shao \& Purpur, 2016). Pendapat lain menyatakan, keterampilan literasi informasi berkaitan dengan kemampuan untuk mengidentifikasi kapan informasi dibutuhkan, dan kompetensi dan keterampilan untuk menemukan, mengevaluasi dan menggunakan informasi dalam membuat keputusan berdasarkan informasi (Ukachi, 2015). Berkait dengan kelima literasi informasi tersebut, dijabarkan menjadi 10 indikator literasi dalam penelitian ini, yaitu: (1) mengenali sumber-sumber informasi; (2) mengenali tipe informasi; (3) memilih cara mengakses informasi melalui internet; (4) menemukan kembali informasi secara online; (5) menetapkan kriteria untuk menilai suatu informasi dari internet; (6) menetapkan kriteria untuk menilai suatu informasi dari buku; (7) menggunakan informasi baru untuk merencanakan dan menciptakan hasil; (8) mengomunikasikan hasil atau kinerja secara tertulis; (9) memahami ragam isu etika, hukum dan sosial ekonomi di seputar informasi dan teknologi informasi; dan (10) mengakui penggunaan sumber-sumber informasi yang digunakan.

\section{Keterampilan Riset}

Abad ini dikenal sebagai abad globalisasi dan abad teknologi informasi. Perubahan yang sangat cepat dan dramatis dalam bidang ini merupakan fakta dalam kehidupan mahasiswa. Di dalam abad 21 peran ilmu pengetahuan (scientific knowledge) menjadi semakin dominan dalam bermasyarakat global. Masyarakat yang perikehidupannya bertumpu pada ilmu pengetahuan dikenal sebagai "masyarakat berbasis pengetahuan" (knowledge-based society) yang perekonomiannya semakin menuju ke ekonomi berbasis pengetahuan (knowledge-based econo$m y$ ), yaitu melalui kegiatan industri jasa maupun produksi yang berbasis pengetahuan atau knowledge-based industry (Amin, 2015). Salah satu tolok ukur keberhasilan kinerja penelitian sesuai Standar Proses Penelitian (Permenristekdikti No. 44 Tahun 2015 pasal 46) menyatakan kegiatan penelitian yang terdiri atas perencanaan, pelaksanaan, dan pelaporan yang memenuhi kaidah dan metode ilmiah secara sistematis sesuai dengan otonomi keilmuan dan budaya akademik. Hal ini sesuai dengan ide pembelajaran yang mengembangkan keterampilan riset (research skills) 
Hasan Subekti, et al., Mengembangkan Literasi Informasi melalui Belajar Berbasis Kehidupan Terintegrasi STEM untuk Menyiapkan Calon Guru Sains dalam Menghadapi Era Revolusi Industri 4.0: Revieu Literatur

berasal dari Visi Humboldt's untuk pendidikan tinggi. Gagasan dia menyatakan "Universities should treat learning as consisting of not yet wholly solved problems and hence always in a research mode" (Blume et al., 2015: 128).

Keterampilan riset (KR) dalam penelitian diukur menggunakan tes tulis dan produk dengan memperhatikan 6 aspek Research Skill Development (RSD) yang dikembangkan oleh Willison (2013: 906), yaitu: (1) memulai penyelidikan (mengajukan pertanyaan atau rumusan masalah, mendesain eksperimen, membuat hipotesis, dan membuat prediksi), (2) menemukan informasi atau menghasilkan data (boolean, truncation, file type, and phrase searching dan mengumpulkan data) (3) mengevaluasi informasi atau data (mengevaluasi informasi), (4) mengelola informasi atau data (menyajikan data), (5) menganalisis, menyintesis dan menerapkan pemahaman baru (menganalisis data), dan (6) mengomunikasikan hasil riset (artikel [baca dan tulis], poster [visual] dan presentasi [aural]) dengan kesadaran akan etika, sosial dan budaya (menggunakan information secara legal \& etis).

\section{Belajar Berbasis Kehidupan}

Abad 21 menimbulkan persaingan antar sumber daya manusia terlebih dalam hal perolehan lapangan pekerjaan (Supahar \& Istiyono, 2015). Persoalan tersebut berkait dengan upaya perbaikan pembelajaran inovatif, di antaranya life-based learning (LBL) atau belajar berbasis kehidupan (BBK) untuk mempersiapkan pebelajar yang siap dalam menghadapi tantangan zamannya. Pembentukan jati diri mahasiswa sebagai manusia utuh yang memiliki kapabilitas yang pola perkembangan secara berkelanjutan.

Life-based learning adalah proses pemerolehan pengetahuan dan keterampilan (skills) memahami hakikat kehidupan, terampil meme- cahkan masalah-masalah kehidupan, menjalani kehidupan secara seimbang dan harmonis (Sudira, 2015). Hal tersebut tentulah selaras dengan tuntutan hidup di abad 21 dan kompetensi mahasiswa yang relevan dengan kebutuhan masyarakat dan lapangan kerja.

Keterampilan berkomunikasi dalam bahasa lisan atau tertulis melalui berbagai media (multi media) menjadi sangat penting (Sudira, 2015) dalam menghadapi era revolusi industri 4.0. Salah satu studi yang berkait dengan pengembangan profesional dilakukan Asghar et al., (2012) yang menunjukkan bahwa pengembangan profesional harus menekankan hubungan yang erat antara konten pedagogi dan materi pelajaran (Asghar et al., 2012). Life-based learning mengetengahkan konsep bahwa belajar dari kehidupan adalah belajar yang sesungguhnya. Dengan kata lain sekolah sejati bagi manusia adalah kehidupannya itu sendiri. Untuk itu, bekerja di Abad 21 membutuhkan kreativitas berpikir dan bekerja dengan cara berkolaborasi dengan orang-orang dari berbagai disiplin kerja dan sosial dan budaya kerja yang berbeda (Sudira, 2015).

\section{STEM Education}

Pengembangan profesional guru untuk pelaksanaan kurikulum tersebut harus diinformasikan oleh pengetahuan praktik terbaik yang ada dalam pengembangan profesional guru, dengan tujuan pendidikan STEM, dan juga dengan sifat pembelajaran berbasis masalah. (Asghar et al., 2012). Peningkatan kemampuan dan keterampilan bagi generasi muda calon tenaga kerja merupakan tanggung jawab dunia pendidikan (Supahar \& Istiyono, 2015). Merujuk pada tujuan utama pendidikan dalam disiplin STEM (sains, teknologi, teknik dan matematika) adalah perolehan keterampilan penelitian untuk mendukung produksi pengetahuan ilmiah. Penelitian 
lebih lanjut untuk mengidentifikasi dampak diskrit dari praktik pendampingan khusus selama rekrutmen fakultas-mahasiswa mengenai pengembangan keterampilan penelitian siswa dan aspek pengembangan ilmiah lainnya akan meningkatkan dasar pembuktian praktik dalam pendidikan (Feldon et al., 2016).

Kegiatan perkuliahan, seharusnya mahasiswa dapat dilatih untuk menjadi pebelajar sepanjang hayat dan pebelajar mandiri (Susilo, 2015). Urgensi keterampilan bernalar dan berpikir ilmiah dalam konteks sosial dan menekankan bahwa literasi saintifik diperuntukkan bagi semua orang, bukan hanya kepada mereka yang memilih berkarier dalam bidang sains dan teknologi (Suwono et al., 2015). Biologi adalah sains utama dan asas dalam kehidupan seharian untuk semua orang. Guru-guru pelajar biologi perlu dilengkapi dengan kepahaman biologi dan kemahiran berpikir kritis untuk mengajar biologi pada masa akan datang (Suwono et al., 2017). Pendidikan STEM memberikan peluang kepada guru untuk memperlihatkan kepada peserta didik betapa konsep, prinsip, dan teknik dari sains, teknologi, enjiniring, dan matematika digunakan secara terintegrasi dalam pengembangan produk, proses, dan sistem yang digunakan dalam kehidupan sehari-hari mereka (Firman, 2015).

Pendidikan STEM (STEM Education) kombinasi area Science, Technology, Engineering, dan Mathematics (STEM) menghubungkan empat bidang dalam kurikulum sains dan menawarkan peluang karier yang dinamis. Delapan standar dan karakteristik pembelajaran yang berusaha mengembangkan STEM education, yaitu (1) mengajukan pertanyaan (untuk sains); (2) mengembangkan dan menggunakan model; (3) merencanakan dan melaksanakan penyelidikan; (4) menganalisis dan menafsirkan data; (5) menggunakan matematika dan berpikir komputasi; (6) membangun penjelasan (untuk sains); (7) melakukan argumen dari bukti; (8) mendapatkan, mengevaluasi, dan mengomunikasikan informasi (Duran, et al., 2016). Sejauh ini gerakan pendidikan STEM telah bergema di berbagai negara, baik negara maju maupun negara berkembang, yang memandang pendidikan STEM sebagai jalan keluar bagi masalah kualitas SDM dan daya saing masing-masing negara (Firman, 2015).

\section{Kompetensi Calon Guru Sains}

Riset, teknologi dan pendidikan tinggi merupakan faktor yang semakin penting dalam membangun daya saing bangsa, meningkatkan kesejahteraan dan keadilan (Kemenristekdikti, 2018c). Dengan demikian, pendidikan harus dapat menyikapi dan mengantisipasi perkembangan liberalisasi pasar kerja, perkembangan masyarakat berbasis ilmu pengetahuan (Santoso et al., 2015) dan meningkatnya perdagangan secara masif serta terjadinya pertukaran budaya keadilan (Kemenristekdikti，2018c). Dalam konteks ini, pendidikan sains sepatutnya membantu orang untuk mempunyai pengetahuan yang mencukupi supaya mereka dapat membuat pilihan yang berpengetahuan, terlibat dalam pembangunan sains, membuat keputusan mengenai isu sains dan impak/dampak mereka terhadap teknologi dan masyarakat, dan memperkayakan pengetahuan saintifik yang diperlukan untuk bekerja di era berasaskan pengetahuan ekonomi (Suwono et al., 2017).

Di abad 21 saat ini peran pendidikan tinggi menjadi penting untuk membekali kemampuan mahasiswa terutama mahasiswa calon guru untuk mampu berperan aktif dalam mengembangkan kapabilitas. Seseorang dikategorikan cakap (capable) adalah mereka yang tahu bagaimana cara belajar; kreatif; memiliki tingkat self-efficacy yang tinggi; dapat menerapkan kompetensi dalam 
Hasan Subekti, et al., Mengembangkan Literasi Informasi melalui Belajar Berbasis Kehidupan Terintegrasi STEM untuk Menyiapkan Calon Guru Sains dalam Menghadapi Era Revolusi Industri 4.0: Revieu Literatur

situasi baru dan akrab; dan bekerja dengan baik dengan orang lain. Elemen-elemen kompetensi yang dirumuskan dalam kurikulum program studi harus pula memuat (1) afeksi, (2) karakter, (3) keterampilan berpikir tingkat tinggi, (4) kemampuan tertentu yang relevan dengan kebutuhan individu, kelompok, masyarakat luar, dan (5) peluang untuk pengembangan diri. Afeksi yang ditumbuh-kembangkan pada mahasiswa Unesa, sesuai dengan landasan kepribadian dan sikap perilaku berkarya di dalam Perpres Nomor 08 Tahun 2012 tentang KKNI (Widodo et al., 2015).

Keterampilan berpikir tingkat tinggi, kemampuan literasi, kewirausahaan, dan life skills, serta kemampuan tertentu seperti kemampuankemampuan yang relevan dengan kebutuhan masyarakat terdekat dan kepentingan integral lembaga), kemampuan-kemampuan tertentu yang menjadi harapan/kebutuhan mahasiswa secara individual maupun kelompok (tecermin pada mata kuliah pilihan), dan peluang bagi mahasiswa untuk mengembangkan diri, seperti melanjutkan studi, mengembangkan pribadi, memperoleh pengetahuan dan pemahaman materi khusus sesuai dengan bidang studi, mengembangkan keterampilan yang dapat dialihkan (transferable skill) dan diorientasikan ke arah karir, atau pemerolehan pekerjaan (Widodo et al., 2015).

\section{Revolusi industri 4.0}

Presiden Republik Indonesia ke-7 Joko Widodo mengungkapkan bahwa salah tantangan kita ke depan harus mampu menguasai bidang intelijen (intelligence) dan bioteknologi serta menguasai hal-hal yang bersifat fisikal (Kemristekti, 2018b). Era ini juga akan mendisrupsi berbagai aktivitas manusia, termasuk di dalamnya bidang ilmu pengetahuan dan teknologi (iptek) serta pendidikan tinggi (Kemristekdikti, 2018a). - Visualisasi mengembangkan Literasi Informasi dan keterampilan riset melalui pembelajaran STEM melalui belajar berbasis kehidupan untuk menyiapkan guru yang siap menghadapi tantangan era 4.0 disajikan pada Gambar 1 sebagai berikut.

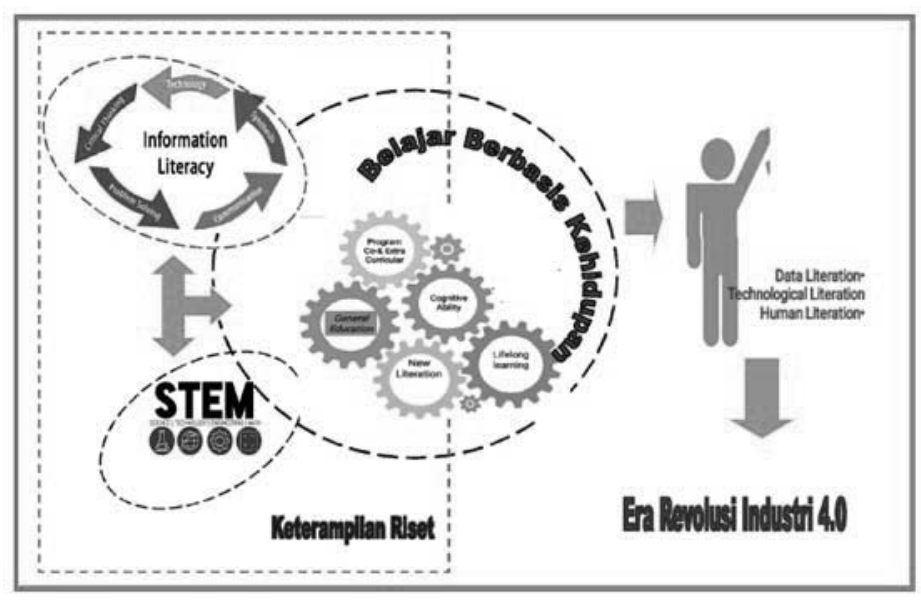

Gambar 1 Visualisasi LI, KR, BBK terinterasi STEM untuk Menghadapi Tantangan Era 4.0

Baru-baru ini, Kemenristekdikti Republik Indonesia mengambil kebijakan terkait program terkait pelaksanaan prioritas nasional dan kementerian yang diarahkan pada penciptaan teknologi masa depan yang mendukung revolusi industri 4.0, dan pemanfaatan teknologi maju untuk meningkatkan nilai tambah sumber daya alam (Kemenristekdikti, 2018c). Hal itu sejalan dengan pandangan Nasir yang menyatakan "Kebijakan strategis perlu dirumuskan dalam berbagai aspek mulai dari kelembagaan, bidang studi, kurikulum, sumber daya, serta pengembangan cyber university, risbang hingga inovasi dalam menghadapi revolusi industri 4.0" (Kemristekdikti, 2018a).

\section{PENUTUP}

\section{Point-Poin Penting}

Berdasar kajian literatur yang telah penulis lakukan, terdapat beberapa poin yang dapat diambil sebagai berikut. 
a. Perubahan dunia kini tengah memasuki era revolusi industri 4.0 atau revolusi industri dunia keempat di mana teknologi informasi telah menjadi basis dalam kehidupan manusia.

b. Literasi informasi merupakan salah satu keterampilan berpikir tingkat tinggi yang dibutuhkan untuk mengembangkan dan mendukung kesuksesan akademis, profesional, dan pribadi.

c. Life-based learning ialah pengembangan ilmu pengetahuan untuk berkontribusi bagi kesejahteraan dan kebahagiaan masyarakat secara seimbang dan harmonis, sehingga menjadi sumber daya manusia yang andal.

d. Pendidikan STEM memiliki banyak manfaat potensial bagi individu dan bangsa secara keseluruhan.

e. Kapabilitas itu adalah suatu karakter menyeluruh yang lebih mudah dikenali daripada didefinisikan. Kapabilitas yang dimaksudkan dalam konteks ini meliputi keterampilan, pengetahuan, dan sikap, yang akan dibawa seseorang ke dunia kerja.

f. Generasi di era industri 4.0 memegang komitmen peningkatan fleksibilitas di bidang manufaktur, secara massal, dengan kualitas dan produktivitas yang lebih baik. Revolusi industri 4.0 meliputi adanya persiapan untuk sistem pembelajaran yang lebih inovatif pada perguruan tinggi, atau menyesuaikan dengan kurikulum yang ada terkait perkembangan teknologi yang begitu pesat.

\section{Rekomendasi}

Beberapa rekomendasi yang dapat penulis berikan antara lain:

a. Perlu dilakukan penelitian yang mendalam tentang cara membelajarkan, bagaimana mengukur, serta mengevaluasinya dalam mengimplementasikan pembelajaran STEM untuk menyiapkan calon guru yang siap menghadapi tantangan Revolusi industri 4.0

b. Pengembangan kapabilitas mahasiswa calon guru IPA kepada seluruh civitas akademika serta mengimplementasikannya di dalam perkuliahan dengan mengintegrasikan STEM perlu penyebarluasan ide dalam bentuk.

\section{DAFTAR PUSTAKA}

ACRL, B. 2016. Framework for Information Literacy for Higher Education. Retrieved from http://acrl.ala.org/framework/

Amin, M. 2015. Biologi Sebagai Sumber Belajar untuk Generasi Masa Kini dan Mendatang yang Berintegritas dan Berperadaban Tinggi, Pidato Pengukuhan Jabatan Guru Besar dalam Bidang Ilmu Biologi pada Fakultas Matematika dan Ilmu Pengetahuan Alam Disampaikan dalam Sidang Terbuka Senat pada Tanggal 17 September 2015. Malang: Universitas Negeri Malang.

Asghar, A., Ellington, R., Rice, E., Johnson, F., \& Prime, G.M. 2012. Supporting STEM Education in Secondary Science Contexts. Interdisciplinary Journal of Problem-Based Learning, 6(2), 85-125. doi:10.7771/15415015.1349.

Beatty, A. 2011. Successful STEM Education A Workshop Summary

Bybee, R.W. 2013. The case for STEM education: Challenges and opportunity. Arlington, Virginia: National Science Teachers Association (NSTA) Press.

Çoklar, A.N., Yaman, N.D., \& Yurdakul, I.K. 2017. Information literacy and digital nativity as determinants of online information search strategies. Computers in $\mathrm{Hu}$ man Behavior, 70, 1-9. doi:10.1016/ j.chb.2016.12.050. 
Hasan Subekti, et al., Mengembangkan Literasi Informasi melalui Belajar Berbasis Kehidupan Terintegrasi STEM untuk Menyiapkan Calon Guru Sains dalam Menghadapi Era Revolusi Industri 4.0: Revieu Literatur

Duran, M., Höft, M., Medjahed, B., Lawson, D.B., \& Orady, E.A. 2016. STEM Learning: IT Integration and Collaborative Strategies. London: Springer

Feldon, D.F., Shukla, K.D., \& Anne Maher, M. 2016. Faculty-student coauthorship as a means to enhance STEM graduate students' research skills. International Journal for Researcher Development, 7(2), 178191. doi:10.1108/ijrd-10-2015-0027

Firman, H. 2015. Pendidikan Sains Berbasis STEM: Konsep, Pengembangan, dan Peranan Riset Pascasarjana. Paper presented at the Seminar Nasional Pendidikan IPA dan PKLH Program Pascasarjana Universitas Pakuan Bogor. https://www.academia.edu/ 21597075/.

Hariastuti, R.T., Prawitasari, J.E., Handarini, D.M., \& Atmoko, A. 2017. The development of critical thinking skills based of patrap triloka's Ki Hadjar Dewantara. International Journal of Development Research, 7(7), 13606-13611. Retrieved from http://www.journalijdr.com/sites/default/files/issue-pdf/9171.pdf

Kanematsu, H., \& Barry, D. M. 2016. STEM and ICT Education in Intelligent Environments. London: Springer International Publishing Switzerland.

Kemenristekdikti. 2018c. Kebijakan Kemenristekdikti Menghadapi Globalisasi Pendidikan \& Revolusi Industri 4.0 [Press release].

Kemristekdikti. 2017. Panduan Teknis Indikator Kinerja Pengembangan Pusat Unggulan Iptek Tahun 2017. Jakarta: Direktorat Jenderal Kelembagaan Iptek dan Dikti.

Kemristekdikti. 2018a. Pengembangan Iptek dan Pendidikan Tinggi di Era Revolusi Industri 4.0. Retrieved from https://www.ristek- dikti.go.id/pengembangan-iptek-dan-pendidikan-tinggi-di-era-revolusi-industri-4-0/

Kemristekti. 2018b. Presiden Jokowi: Tantangan Kita Kedepan, Revolusi Industri 4.0. Retrieved from https://www.ristekdikti.go.id/ presiden-jokowi-tantangan-kita-kedepanrevolusi-industri-4-0/

Rialita, N. 2018. Era Revolusi Industri 4.0, Pembelajaran PT Harus Lebih Inovatif. Retrieved from http://sumut.pojoksatu.id/ 2018/01/17/era-revolusi-industri-4-0-pembelajaran-pt-harus-lebih-inovatif/

Santoso, M., Putra, A., Muhidong, J., Sailah, I., Mursid, S., Rifandi, A. Endrotomo. 2015. Kerangka Kualifikasi Nasional Indonesia. Jakarta: Direktorat Jenderal Pembelajaran dan Kemahasiswaan.

Schroeter, C. \& Higgins, L.M. 2015. The Impact of Guided vs. Self-directed Instruction on Students' Information Literacy Skills. Journal for Advancement of Marketing Education, 23(1), 1-10.

Shao, X., \& Purpur, G. 2016. Effects of Information Literacy Skills on Student Writing and Course Performance. The Journal of Academic Librarianship, 42(6), 670-678. doi:10.1016/j.acalib.2016.08.006.

Subekti, H., Susilo, H., Ibrohim, \& Suwono, H. 2017. Patrap Triloka Ethno-Pedagogy With Research-Based Learning Settings to Develop Capability of Pre-Service Science Teachers: Literature Review. Paper presented at the 1 st International Conference on Mathematics, Science, and Education (ICoMSE 2017), Malang.

Sudira, P. 2015. Pengembangan Model "Lis-5c" pada Pendidikan Teknologi dan Kejuruan. Cakrawala Pendidikan, 34(1), 1-11. doi: 10.21831/cp.v1i1.4145 
Supahar, \& Istiyono, E. 2015. Pengembangan Asesmen Kinerja Berbasis STEM untuk Meningkatkan Softskill dan Hardskill Peserta Didik pada Pembelajaran Fisika SMA (Vol. 1-72). Provinsi Daerah Istimewa Yogyakarta: DIPA BLU Universitas Negeri Yogyakarta.

Susilo, H. 2014. Peningkatan Kualitas Pembelajaran Biologi untuk Membentuk Guru Biologi yang Profesional dan Cerdas. Florea, 1(1), 1-9. Retrieved from http://ejournal.unipma.ac.id/index.php/JF/article/ view/364/336.

Susilo, H. 2015. The Development of Some 21st Century Skills through Lesson Studybased Classroom Action Research to Improve the Teaching Learning Quality of Plant Physiology Course. Paper presented at the Seminar Nasional Pendidikan Biologi 2015 tema: "Peran Biologi dan Pendidikan Biologi dalam Menyiapkan Generasi Unggul dan Berdaya Saing Global”, Malang. http://biology.umm.ac.id/files/file/729741\%20Herawati\%20Susilo.pdf.

Susilo, H., Ibrohim, \& Suwono, H. 2017. Pengembangan Kapabilitas Peserta Didik Melalui Belajar Berbasis Kehidupan dalam Pembelajaran Biologi (pp. 1-20). Malang: DRPM Ditjen Penguatan Risbang, Kemristekdikti.
Suwono, H., Pratiwi, H. E., Susanto, H., \& Susilo, H. 2017. Enhancement of students' biological literacy and critical thinking of biology through socio-biological case-based learning. Jurnal Pendidikan IPA Indonesia, 6(2), 213-220. doi:10.15294/ jpii.v6i2.9622.

Suwono, H., Rizkita, L., \& Susilo, H. (2015). Peningkatan literasi saintifik siswa sma melalui pembelajaran biologi berbasis masalah sosiosains. Jurnal Ilmu Pendidikan, 21(2), 136-144.

Ukachi, N.B. 2015. Exploration of Information Literacy Skills Status and Impacts on the Quality of Life of Artisans in Lagos, Nigeria. New Library World, 116(9/10), 578587. doi:10.1108/nlw-01-2015-0006.

Widodo, W., Setiawan, B., Astriani, D., Budiyanto, M., \& Rosdiana, L. 2015. Laporan Kegiatan Sanctioning Tahap 2: dalam Rangka Pengembangan Kurikulum Program Studi Pendidikan IPA. Program Studi S-1 Pendidikan IPA, Fakultas Matematika dan Ilmu Pengetahuan Alam, Universitas Negeri Surabaya. (pp. 1-63). Surabaya: PIU IDB Unesa.

Zhong, R. Y., Xu, X., Klotz, E., \& Newman, S. T. 2017. Intelligent Manufacturing in the Context of Industry 4.0: a Review. Engineering, 3(5), 616-630. doi:10.1016/ j.eng.2017.05.015. 